MedieKultur | Journal of media and communication research | ISSN 1901-9726

Article - Classics section

\title{
Framing: \\ Til afklaring af et spredt paradigme
}

\author{
Robert M. Entman
}

Artiklen er oversat af Stig Hjarvard

MedieKultur 2015, 58, 115-123

Published by SMID | Society of Media researchers In Denmark | www.smid.dk The online version of this text can be found open access at www.mediekultur.dk

I denne klassiske artikel om framing-begrebet giver Robert M. Entman en udfoldet definition af framing, ligesom han argumenterer for, at frames findes i hele kommunikationsprocessen, dvs. hos afsenderen, i teksten, hos modtageren og i kulturen. Framing-begrebet har veret anvendt i mange discipliner, men kommunikationsforskningen kan med fordel vare den centrale overdisciplin, der samler spredte bidrag til en konsistent definition af begrebet. Kommunikationsforskningen kan på denne måde dels styrke sin egen teoretiske stringens og dels bidrage til afklaring af en rakke problemer i forskellige andre discipliner vedr. teksters betydning og indflydelse. Artiklen er oprindeligt publiceret i Journal of Communication i 1993.

Jeg vil foreslå, at vi som svar på påstanden om, at kommunikationsfeltet ikke har status af en egentlig disciplin pga. en manglende kerne af fælles viden, vender en tilsyneladende svaghed til en styrke. Vores mission bør være at bringe indsigter og teorier sammen, der ellers ville forblive spredt blandt andre discipliner. Som følge af den manglende udveksling mellem discipliner kan hypoteser opnå bred anerkendelse i én disciplin, selvom de er dybt miskrediteret i en anden. Potentielle forskningsparadigmer kan forblive splittede med brudstykker spredt her og dér, men uden en overgribende fremstilling til at vejlede forskningen. Ved at bringe idéer sammen på ét sted kan kommunikationsforskningen stræbe efter at blive en overdisciplin, der syntetiserer beslægtede teorier og begreber og udsætter 
dem for den mest omhyggelige og omfattende afklaring og undersøgelse. For at nå dette mål kræver det en mere selvbevidst vilje blandt kommunikationsforskere til at undersøge andre områder og kommunikere deres resultater til udenforstående forskere. Et sådan initiativ ville samtidig styrke den egentlige kommunikationsvidenskabs teoretiske stringens.

Idéen om 'framing'1 udgør et casestudie i netop den form for spredt begrebsliggørelse, jeg har identificeret. På trods af at begrebet er allestedsnærværende på tværs af samfundsog humanvidenskaberne, er der ikke noget sted en generel redegørelse for framing-teori, der præcist viser, hvordan frames bliver indlejret i og manifesterer sig i en tekst, eller hvordan framing påvirker tænkning. En analyse af dette begreb demonstrerer, hvordan kommunikationsforskningen kan bidrage med noget unikt: En syntetisering af den forskelligartede brug af begrebet vil vise, hvordan framing er uløseligt forbundet med kommunikation, og på den baggrund kan der konstrueres en kohærent teori.

Uafhængig af den konkrete brug tilbyder begrebet om framing en måde at beskrive, hvordan en kommunikerende tekst udøver magt. En framing-analyse belyser den præcise måde, hvorpå den menneskelige bevidsthed påvirkes gennem overførsel (eller kommunikation) af information fra et 'sted' - som eksempelvis en tale, en ytring, en nyhedshistorie eller en roman - til bevidstheden. (En repræsentativ liste over klassiske og nyere referencer vil inkludere Edelman, 1993; Entman \& Rojecki, 1993; Fiske \& Taylor, 1991; Gamson, 1992; Goffman, 1974; Graber, 1988; lyengar, 1991; Kahneman \& Tversky, 1984; Pan \& Kosicki, 1993; Riker, 1986; Snow \& Benford, 1988; Tuchman, 1978; White, 1987; Zaller, 1992). En gennemgang af faglitteraturen peger på, at framing ofte defineres på en lemfældig måde, hvor meget overlades til læserens og forskerens uudtalte forståelse. Ord som frame, framing og framework er jo ganske almindelige uden for den formelle forskningsmæssige diskurs, og deres medbetydninger er i store træk de samme. Formålet er her at identificere og tydeliggøre fælles tendenser på tværs af den varierende brug af begreberne og at foreslå en mere præcis og universel forståelse af dem.

\section{Om frames og framing}

Grundlæggende set involverer framing udvcelgelse og fremhæevning. At frame består i at udvalge nogle aspekter af erfaringsverdenen og fremhave dem i en kommunikativ tekst på en sådan måde, at der anspores til en bestemt definition af problemet, fortolkning af årsager, moralsk evaluering og/eller anbefaling af (be)handling for det pågældende tilfælde. Det typiske er, at frames stiller en diagnose, evaluerer og foreskriver, hvilket Gamson (1992) har vist på den mest grundige måde. Et eksempel er den 'koldkrigs'-frame, som indtil for nylig dominerede udenrigsnyheder i USA. Koldkrigs-framen fremhævede bestemte udenlandske begivenheder - eksempelvis borgerkrige - som problemer, identificerede deres årsager (kommunistiske oprørere), tilbød moralske vurderinger (ateistisk aggression) og anbefalede bestemte løsninger (amerikansk støtte til den anden side). 
Heraf følger, at frames definerer problemer - afgør hvad en handlende aktør udvirker med deraf følgende omkostninger og gevinster, sædvanligvis vurderet i forhold til fælles kulturelle værdier; de diagnosticerer årsager - identificerer de faktorer, der skaber problemet; de foretager moralske vurderinger - evaluerer kausale aktører og deres effekter; og de foreslår en behandling - tilbyder og retfærdiggør problemløsninger og deres mulige effekter. En enkelt sætning kan foretage mere end én af disse fire framing-funktioner, mens mange sætninger i en tekst ikke behøver tjene nogle af dem. Og i den enkelte teksts tilfælde behøver en frame ikke nødvendigvis at inkludere alle fire funktioner.

Eksemplet med den kolde krig peger på, at frames findes mindst fire steder i kommunikationsprocessen: afsenderen, teksten, modtageren og kulturen. Afsenderen foretager bevidste eller ubevidste framing-valg ved at formulere udsagn under indflydelse af de frames (ofte kaldes skemata), som organiserer vedkommendes forestillingsunivers. Teksten indeholder frames, der er synlige ved tilstedeværelsen eller fraværet af bestemte nøgleord, faste vendinger, stereotype billeder, bestemte informationskilder samt sætninger, der tematisk underbygger et sæt af fakta og vurderinger. De frames, som informerer modtagerens tænkning og konklusion, kan reflektere de frames, som findes i teksten, og som præger afsenderens intention, men de behøver ikke at gøre det. Kulturen er lageret af typisk påkaldte frames; kulturen kan netop defineres som de empirisk konstatérbare sæt af gængse frames, der fremtræder i diskursen og tænkningen hos hovedparten af mennesker inden for en given social gruppering. Alle fire steder rummer framing ensartede funktioner: udvælgelse og fremhævning, brug af fremhævede elementer til at konstruere et argument omkring problemer og deres årsager, evaluering og/eller løsning.

\section{Hvordan frames virker}

Frames tydeliggør udvalgte dele af den information, der gives om et emne i en kommunikationsproces, og derved fremhæves deres vigtighed. Ordet 'fremhævning' (engelsk: 'salience') behøver i sig selv en definition: Det betyder at gøre en oplysning mere bemærkelsesværdig, meningsfuld og erindringsværdig for modtagerne. En stærkere fremhævning øger sandsynligheden for, at modtagerne vil opfatte informationen, forstå dens betydning og følgelig behandle og lagre den i hukommelsen (se Fiske \& Taylor, 1991).

Tekster kan gøre oplysninger mere fremtrædende i kraft af deres placering eller gentagelse eller ved at knytte dem til kulturelt velkendte symboler. Men selv forekomsten af et enkelt begreb et upåagtet sted $i$ teksten uden brug af billedlige virkemidler kan have en fremtrædende virkning, hvis det harmonerer med eksisterende skemata $i$ en modtagers forestillingsunivers. Af samme grund kan fremhævningen af en idé i en tekst være svær at bemærke, fortolke eller huske for modtagerne som følge af deres egne mentale skemata. I vores sammenhæng forstår vi skemata og tilsvarende begreber som kategorier, 'scripts' eller stereotyper som de mentalt lagrede mønstre af idéer, som guider individets informationsbehandling (se eksempelvis Graber, 1988). Da fremhævningen er et produkt af inter- 
aktionen mellem tekster og modtagere, er forskerens identifikation af frames i teksten ikke nogen garanti for, at de påvirker publikums tænkning (Entman, 1989; Graber, 1988).

Kahneman og Tversky (1984) giver det måske mest citerede, nylige eksempel på framingens magt og dens virkemåde gennem udvælgelse og fremhævning af nogle aspekter af virkeligheden på bekostning af andre. Forfatterne stillede følgende opgave til personer $\mathrm{i}$ et eksperiment:

\footnotetext{
Forestil dig, at USA er ved at forberede sig på udbruddet af en usædvanlig asiatisk sygdom, som forventes at slå 600 mennesker ihjel. Der er foreslået to alternative programmer til at bekæmpe sygdommen. Vi antager, at de eksakte videnskabelige estimater over de to programmers konsekvenser er følgende: Hvis program A anvendes, vil 200 mennesker blive reddet. Hvis program $B$ anvendes, er der en tredjedel sandsynlighed for, at 600 mennesker vil blive reddet og to-tredjedel sandsynlighed for, at ingen mennesker vil blive reddet. Hvilket af de to programmer vil du anbefale? $(1984$, p. 343$)$.
}

I dette eksperiment valgte 72 procent af deltagerne program A; 28 procent valgte program B. I det næste eksperiment blev der opstillet helt tilsvarende valgmuligheder for handling $\mathrm{i}$ den selvsamme situation, men nu blev de framed i form af sandsynlige dødsfald i stedet for reddede menneskeliv: "Hvis program C anvendes, vil 400 mennesker $\mathrm{d} \varnothing$. Hvis program D anvendes, er der en tredjedel sandsynlighed for, at ingen vil dø og to-tredjedel sandsynlighed for at 600 mennesker vil dø" (Kahneman \& Tversky, 1984, p. 343). Den procentvise fordeling af respondenternes valg blev vendt om som følge af framingen. Program $C$ blev valgt af 22 procent, selvom det tilsvarende program $A$ blev valgt af 72 procent; og program $D$ fik opbakning fra 78 procent, mens det identiske program B kun fik tilslutning fra 28 procent.

Som dette eksempel så levende illustrerer, afgør framingen, hvorvidt et problem bemærkes, forstås og huskes af hovedparten af modtagerne, samt hvordan de evaluerer problemet og beslutter sig for at handle efterfølgende. Begrebet om framing indebærer således, at en frame har en generel effekt på store dele af det modtagende publikum, selvom det ikke er sandsynligt, at den har en universel effekt på alle.

Kahneman og Tverskys eksperimenter demonstrerer, at frames giver opmærksomhed til udvalgte dele af den beskrevne virkelighed, hvad der logisk indebærer, at frames på samme tid bortleder opmærksomheden fra andre dele. De fleste frames er defineret af såvel det, de udelukker, som det, de inkluderer, og udelukkelsen af mulige definitioner af et problem og tilhørende forklaringer, vurderinger og anbefalinger kan være lige så kritiske for styringen af publikums forståelse, som inklusionen af sådanne kan være.

Edelman understreger den måde, hvorpå frames udøver indflydelse gennem selektiv beskrivelse og udeladelse af kendetegn ved en situation:

Ethvert fænomens egenskaber, årsager og konsekvenser bliver radikalt forskellige, når der foretages ændringer i, hvad der får en fremtrædende placering, hvad der udelades, og især hvordan observationer klassificeres (..) [D]en sociale verden er (..) et kalejdoskop af mulige 
virkeligheder, som alle let kan fremkaldes ved at ændre på de måder, hvorpå observationer frames og kategoriseres. (1993, p. 232)

Modtageres reaktioner påvirkes tydeligt, hvis de forstår og behandler information ud fra én fortolkning og har ringe eller uforenelig information om alternativer. Det er årsagen til, at udelukkelse af fortolkende frames er lige så afgørende for udfaldet som inkludering.

Sniderman, Brody og Tetlock (1991) leverer et tydeligt eksempel på den magtfulde betydning af tilvalg og fravalg i framing:

Framing har som effekt, at værdier forlods tillægges forskellig vægt, at den ene eller den anden fremhæves. [Derfor] (..) støtter et flertal af opinionen AIDS-ramte personers rettigheder, når emnet [i en spørgeskemaundersøgelse] frames som et spørgsmål om borgerrettigheder - og støtter (..) tvungen AIDS-test, når emnet frames som et spørgsmål om folkesundhed. (p. 52)

Teksten i spørgeskemaundersøgelsen forsyner de fleste mennesker med de hensyn, der indgår i deres overvejelser, når de skal svare på spørgsmålet om AIDS-test (Zaller, 1992). En potentiel anden og modgående framing af emnet er ofte enten helt eller delvist fraværende i en tekst, endskønt en modtager, for at blive ved dette eksempel, med en stærk borgerrettighedsfølelse måske vil afvise brug af tvungen test, selvom undersøgelsen udelukkende framede AIDS som et spørgsmål om folkesundhed.

\section{Frames i politiske nyheder}

Denne forståelse af framing har vigtige konsekvenser for politisk kommunikation. Frames tildeler visse sider af virkeligheden opmærksomhed, mens andre sider tilsløres, hvilket kan lede publikum til forskellige reaktioner. Politikere på jagt efter stemmer anspores derfor til at konkurrere med hinanden og med journalister om framing af nyheder (Entman, 1989; Riker, 1986). Set i dette lys spiller framing en betydelig rolle i udøvelsen af politisk magt, og framingen af en nyhedshistorie er faktisk magtens aftryk - den registrerer og identificerer de aktører eller interesser, som konkurrerede om at dominere teksten.

Som afspejling af magtspillet og grænserne for diskursen om et bestemt emne udviser mange nyhedstekster en homogen framing på ét analyseniveau, mens de på et andet niveau rummer konkurrerende frames. I debatten om USA's politik over for Irak forud for krigen [Golfkrigen 1990-91, oversætterens bemærkning] var der således en stiltiende konsensus blandt USA's eliter om ikke at argumentere for sådanne handlemuligheder som forhandling mellem Irak og Kuwait. Nyhedsframen indeholdt kun to handlemuligheder, øjeblikkelig krig eller øjeblikkelige sanktioner med (forventelig) efterfølgende krig, mens problemdefinitioner, årsagsanalyser og moralske vurderinger var homogene. Blandt de udpegede handlemuligheder var der imidlertid strid mellem eliterne om framingen, og nyhedsdækningen tilbød forskellige sæt af fakta og evalueringer. Irak-eksemplet røber, at nyheds-framingens magt kan være selvforstærkende. Under debatten forud for krigen ville enhver kritik, der overskred de handlemuligheder, som framingen tillod (snarlig krig eller mere tid til sanktioner), bryde med grænserne for acceptabel diskurs, og som følge deraf havde den ringe 
mulighed for at påvirke politikken. Efter sædvanlige journalistiske standarder blev sådanne synspunkter ikke vurderet som nyhedsværdige (Entman \& Page, under udgivelse). Når disse synspunkter ikke blev offentliggjort, kunne de ikke få mange tilhængere eller skabe nogen oplevet eller reel indflydelse på den offentlige mening, hvorfor eliterne ikke oplevede noget pres for at udvide framingen, så den kom til at inkludere andre handlemuligheder over for den irakiske aggression, som eksempelvis forhandling. På linje hermed påpeger Gamson (1992), at en frame kan udøve stor samfundsmæssig magt, når den indkodes i et begreb som positiv sæerbehandling. Når først et begreb har opnået bred anerkendelse, indebærer brugen af et andet en risiko for, at målgruppen vil opfatte afsenderen som mindre troværdig - eller helt vil mangle evnen til at forstå, hvad afsenderen taler om. På denne måde kan framingens magt være lige så stor som selve sprogets magt.

\section{Fordele ved et konsistent framing-begreb}

En forståelse af frames er en hjælp til at belyse mange empiriske og normative uenigheder, i særdeleshed fordi begrebet om framing henleder vores opmærksomhed på detaljerne i, hvordan en kommunikerende tekst mere præcist udøver sin magt. Eksemplet fra massekommunikationens verden, som vi her har undersøgt, peger på, hvordan en fælles forståelse kan bidrage til at etablere framing som et forskningsparadigme. Et forskningsparadigme er her defineret som en generel teori, der informerer det meste af forskningen om funktionsmåden og konsekvenserne af givent system for tanke og handling. Framingparadigmet kunne med tilsvarende fordele appliceres på studiet af den offentlige meningsdannelse og vælgeradfærd i statsvidenskaben; på studiet af kognition i socialpsykologien; eller til forskning i klasser, køn og race inden for kulturstudier og sociologi, for at nævne nogle få. Her følger nogle eksempler fra teoretiske debatter inden for massekommunikationsforskningen til at anskueliggøre, hvordan de vil kunne drage fordel af en eksplicit og fælles forståelse af framing-begrebet.

1. Publikums autonomi. Framing-begrebet giver mulighed for en operationel definition af forestillingen om en dominerende betydning, der er så central i diskussioner om polysemi og publikums selvstændige afkodning af medietekster (Fiske, 1987). Ud fra et framingperspektiv består den dominerende betydning af de fortolkninger af problemets definition, årsager, evalueringer og handlingsanvisninger, som har den største sandsynlighed for at blive bemærket, bearbejdet og accepteret af flest mennesker. At identificere en betydning som dominerende eller foretrukken er at pege på en bestemt framing af situationen, som finder størst støtte i teksten og er kongruent med de mest gængse skemata blandt publikum.

Framing-paradigmet fraråder forskerne at tage afsæt i spredte tekstdele for at vise, hvordan de kunne blive fortolket på måder, der modsiger den dominerende betydning. Hvis en tekst-frame på en række forskellige og gensidigt understøttende måder understreger, at glasset er halvt fyldt, peger samfundsvidenskabens resultater på, at relativt få blandt publikum vil konkludere, at det er halvt tomt. Hvis man vil argumentere for, at polysemiske 
egenskaber ved meddelelsen bidrager til en sådan modgående framing, må forskerne være i stand til at vise, hvordan den virkelige verdens publikummer re-framer meddelelsen, og at denne re-framing ikke er et biprodukt af omstændigheder ved forskningen - eksempelvis en fokusgruppediskussion, hvor en deltager kan føre an i diskussionen, eller en interviewguide med ledende spørgsmål (Budd, Entman, \& Steinman, 1990).

Mennesker kan ganske givet genkalde sig deres egne fakta, skabe forbindelser, der ikke er eksplicitte i teksten, eller fra hukommelsen hente en årsagsforklaring eller handlingsanvisning, som er fuldstændig fraværende i teksten. Dette er grundlæggende set blot, hvad æærere vanemæssigt tilskynder studerende til at gøre. Men som blandt andre Zaller (1992), Kahneman og Tversky (1984) og lyengar (1991) har peget på, er folk sædvanligvis ikke så velinformerede og kognitivt aktive, når det gælder de fleste emner af samfundsmæssig eller politisk interesse, og framing kan derfor i høj grad udøve indflydelse på deres indstilling til kommunikationen, om end Gamson (1992) beskriver betingelser, der kan dæmpe denne indflydelse.

2. Journalistisk objektivitet. Journalister kan følge reglerne for 'objektiv' rapportering og alligevel formidle en dominerende framing af nyhedsteksten, som forhindrer de fleste blandt publikum i at foretage en balanceret vurdering af en situation. Netop fordi de mangler en fælles forståelse af framing, tillader journalister jævnligt de mest dygtige mediemanipulatorer at præge nyhederne med deres dominerende frames (Entman, 1989; Entman \& Page, under udgivelse; Entman \& Rojecki, 1993). Hvis journalisterne blev uddannet til at forstå forskellen mellem at inkludere spredte, modsigende fakta og at udfordre en dominerende framing, kunne de blive bedre udrustet til at konstruere nyheder, som - også for det gennemsnitlige, uopmærksomme og sporadisk informerede publikum - gjorde to eller flere fortolkninger af problemer lige fremtrædende. En sådan opgave vil kræve, at journalisterne påtager sig en langt mere aktiv og kompleks rolle end tilfældet er i dag, men resultatet vil være en mere balanceret journalistik end den, der produceres efter den skabelonagtige norm om objektivitet (Tuchman, 1978).

3. Indholdsanalyse. Den vigtigste opgave med at forstå en teksts mening bør være at identificere og beskrive frames; når indholdsanalysen informeres af en teori om framing, kan man undgå at behandle alle negative og positive udtryk og ytringer som lige fremtrædende og indflydelsesrige. Det sker ofte, at de personer, der foretager kodningen af indhold, ganske simpelt lægger de budskaber sammen, som de vurderer er positive eller negative, og deraf drager konklusioner om de dominerende betydninger. De undlader at registrere, hvorvidt de enkelte elementer har en fremtrædende karakter i teksten, og formår ikke at vurdere sammenhængen mellem de mest fremtrædende sæt af meddelelser - tekstens frames - og publikums skemata. Uden støtte fra et framing-paradigme kan indholdsanalyse ofte levere data, der fejlrepræsenterer de mediebudskaber, som hovedparten af publikum faktisk tager til sig.

4. Offentlig mening og normativ demokratisk teori. I Zallers (1992) redegørelse fremstår framing som en afgørende magt i den demokratiske proces, idet politiske eliter kontrolle- 
rer, hvordan emner frames. Disse frames kan netop afgøre, hvad 'den offentlige mening' er - ifølge Zaller kan en alternativ frame og opinionsundersøgelser og selv valgresultater indikere en anden offentlig mening. Hans teori synes, på tilsvarende måde som Kahneman og Tverskys teori, at rejse fundamental tvivl om selve demokratiet. Hvis eliterne ved at præge framingen kan bestemme de vigtigste manifestationer af den 'sande' offentlige mening, som en regering har til rådighed (via meningsmålinger og stemmeafgivning), hvad kan den sande offentlige mening så være? Hvordan kan selv oprigtige, demokratiske repræsentanter reagere korrekt på den offentlige mening, når det empiriske belæg for den ser ud til at være så letpåvirkeligt, så sårbart over for framing-effekter?

Lad os sige, at der er tre måder at frame et emne på, og den ene opnår 40 procents tilslutning, de andre henholdsvis 50 og 60 procent. En godkendelse af valgmuligheden med 60 procents tilslutning er aksiomatisk ikke den mest demokratiske reaktion på grund af det cykliske majoritetsproblem (Riker, 1986), der gør flertalsstyre i situationer med mange komplekse valgmuligheder matematisk umuligt. Lige så vigtigt er det, at et forsøg på at bestemme, hvilke af de forskelligt framede holdninger der er tættest på offentlighedens 'virkelige' stemning, virker futilt, da det ville forudsætte en enighed mellem rivaliserende eliter og borgere om, hvilken frame der er den mest akkurate, fair, dækkende osv. Et framing-paradigme kan belyse, hvis ikke løse, sådanne vanskelige problemer i normativ demokratiteori.

Framing-begrebet er så sandelig tilstrækkeligt vigtigt inden for de mange undersøgelsesfelter, hvor det anvendes, at det fortjener en fremstilling i boglængde. Den foreliggende bestræbelse er begrænset af pladsen og leverer ikke det sidste ord om framing, men er et foreløbigt bidrag. Ligeså vigtigt er det, at denne artikel eksemplificerer, hvordan kommunikationsforskningen fra sit brede virkefelt og sine eklektiske tilgange kunne udvikle en kerne af viden, som kan omsættes til forskningsparadigmer med bidrag til samfundsvidenskabelig teori i bredeste forstand.

\section{Litteratur}

Budd, M., Entman, R.M., \& Steinman, C. (1990). The Affirmative Character of U.S. Cultural Studies. Critical Studies in Mass Communication, 7, 169-184.

Edelman, M.J. (1993). Contestable Categories and Public Opinion. Political Communication, 10(3), 231-242.

Entman, R.M. (1989). Democracy Without Citizens: Media and the Decay of American Politics. New York: Oxford University Press.

Entman R.M. (1993). Framing: Toward Clarification of a Fractured Paradigm. Journal of Communication, 43(4), 51-58.

Entman, R M., \& Page, B.I. (in press). The News Before the Storm: The Iraq War Debate and the Limits to Media Independence. In W.L. Bennett \& D.L. Paletz (Eds.), Just Deserts; The News Media, U.S. Foreign Policy, and the Gulf War. Chicago: University of Chicago Press. 
Entman, R.M., \& Rojecki, A. (1993). Freezing out the Public: Elite and Media Framing of the U.S. Anti-Nuclear Movement. Political Communication, 10(2), 151-167.

Fiske, J. (1987). Television Culture. New York: Routledge.

Fiske, S.T., \& Taylor, S.E. (1991). Social Cognition. New York: McGraw-Hill.

Gamson, W. (1992). Talking Politics. New York: Cambridge University Press.

Goffman, E. (1974). Frame Analysis. New York: Free Press

Graber, D.A. (1988). Processing the News: How People Tame the Information Tide (2.udg.). New York: Longman.

Iyengar, S. (1991). Is Anyone Responsible? Chicago: University of Chicago Press.

Kahneman, D., \& Tversky, A. (1984). Choice, Values, and Frames. American Psychologist, 39, 341-350.

Pan, Z., \& Kosicki, G.M. (1993). Framing Analysis: An Approach to News Discourse. Political Communication, 10(1), 55-76.

Riker, W.H. (1986). The Art of Political Manipulation. New Haven: Yale University Press.

Sniderman, P.M., Brody, R. A., \& Tetlock, P. E. (1991). Reasoning and Choice: Explorations in Political Psychology. Cambridge, England: Cambridge University Press.

Snow, D.A., \& Benford, R.D. (1988). Ideology, Frame Resonance, and Participation Mobilization. International Social Movement Research, 1, 197-217.

Tuchman, G. (1978). Making News. New York: Free Press.

White, H. (1987). The Content of the Form. Baltimore, MD: Johns Hopkins University Press.

Zaller, J.R. (1992). The Nature and Origins of Mass Opinion. New York: Cambridge University Press.

\section{Noter}

1 I denne oversættelse anvendes de engelske udtryk 'frame' og 'framing'. De kan udmærket oversættes til danske ord som fx 'en fortolkningsramme' ('frame' som substantiv), 'at rammesætte' eller 'at indramme' ('frame' som verbum) og 'rammesætning' ('framing'), men de engelske udtryk har også i den danske faglitteratur vundet indpas som gængse betegnelser.

Robert M. Entman

Professor, Ph.D.

School of Media and Public Affairs

George Washington University

entman@gwu.edu 